Wojciech Ryczek (D) https://orcid.org/0000-0003-3288-1642

Jagiellonian University in Kraków

wojciech.ryczek[at]uj.edu.pl

\title{
Epistola Erudita of Justus Lipsius
}

\begin{abstract}
This paper presents (in the form of transcription and translation) a letter written by a humanist and classical scholar, Iustus Lipsius (1547-1606), which its Cracow editor entitled Epistola erudita (1602). The rhetorical analysis of this text is based on Lipsius' treatise Epistolica institutio (The Principles of Letter-Writing). The main problem concerns the role of traditional rhetoric in epistolography, especially if the letter is not reduced to a formal document built of template formulas. Early-modern epistolography (Petrarca, Erasmus, Lipsius, Vives) revives the ancient tradition of writing letters, according to which a letter is a kind of written conversation. It gives the sender and the addressee a unique opportunity to meet each other in the symbolic universe of the text.
\end{abstract}

Keywords: Lipsius, Adreas Schoen, ars epistolandi, rhetoric

* Polish text: W. Ryczek, "Justusa Lipsjusza Epistola Erudita," Terminus 23/12 (2010), pp. 79-93. 
Celso gaudere et bene rem gerere Albinovano / Musa rogata refer, comiti scribaeque Neronis.

Horace, Epistulae, I, 8, 1-2

accipe quo semper finitur epistula verbo, / (atque meis distent ut tua fata!) "vale".

Ovid, Tristia, V, 13, 33-34

In 1602, the Lazarus Printing House published a small print of eight pages in quarto, whose full title read: Iusti Lipsii, viri doctissimi ad Andream Schoneum, in Academia Cracoviensi Theologum, Epistola erudita. ${ }^{1}$ In a short dedication letter, which plays the important role of a dedication preface, Lazarus explained the motifs of his publishing decision to future readers of the print, especially young students (Studiosae Iuventuti), whom he addressed directly:

Ecce habes epistolam Iustii Lipsii, viri incomparabilis, quam his diebus ad Andream Schoneum, unum ex Academicis nostris, misit. Eam ego typis mandare volui, ut intelligas, quam praeclare de nostris hominibus vir doctissimus sentiat et ut tu maiori deinceps studio ad omne decus litterarum nitaris atque incumbas. Vale et Lipsii opinioni de te conceptae respondere, satage.

[Here is a letter from an unparalleled man, Iustus Lipsius, sent recently to Andreas Schoen, one of our academics. I decided to print it so that you could all learn about the excellent opinion that this highly learned man holds of our people and so that you could be more inclined and seek all the beauty of literature more eagerly. Farewell and try to satisfy the opinion of Lipsius about yourself. $\left.{ }^{2}\right]$

Lipsius' letter was supposed to become an encouragement (adhortatio) for students to devote themselves to studies with even more

1 See A. Borowski, Iter Polono-Belgo-Ollandicum. Cultural and literary relationships between the Commonwealth of Poland and the Netherlands in the $16^{\text {th }}$ and $17^{\text {th }}$ centuries, Cracow 2007, pp. 115-117.

2 This edition of Lipsius' letter is based on the aforementioned edition of 1602 (BJ 16942 I). I would like to thank Professor Elwira Buszewicz for her help in translating the text into Polish. 
energy and enthusiasm. Jan Tęczyński, a senior pupil of the University of Cracow, was an example to follow. He gained recognition and praise for his systematic work on exploring the liberal arts. The opinion expressed about one of Schoen's students by a professor from Leuven, which is far away from Cracow, becomes a collective summon addressed to all those who cross the threshold of the Cracow University. For other members of the academic community, the individual praise becomes an obligation. If one cannot exceed the fame of Tęczyński, then they should at least try to spend as much time as possible on acquiring and deepening knowledge. The decision to issue the letter to Schoen was therefore based on a teacher's concern to provide his students with a good example of proper conduct and to encourage fair competition (academic agon) in the acquisition of wisdom. Therefore, Lazarus assumed a specific reading-mode for the letter, the concise description of which is a well-known verse from Horace's poetry: "mutato nomine de te fabula narratur" ("the story speaks of you under a changed name", Sermones I, 1, 69-70). Paraphrasing the above statement, we can say that Lipsius' words about Schoen's disciple also apply to you, the reader, who perhaps come across a humanist letter from Leuven purely by chance. To investigate this letter, I propose to use the categories developed by Lipsius in his treatise entitled Epistolica institutio, ${ }^{3}$ which is both a general exposition of the Renaissance theory of epistolography developed on the basis of lectures given at the University of Leiden in $1587^{4}$ and a detailed indication of specific formal solutions that determine the specificity

3 See M. Fumaroli, L'Âge de l'éloquence : rhétorique et "res literaria " de la Renaissance au seuil de lépoque classique, Genève 1980, pp. 152-159; M. Morford, "Life and letters in Lipsius's teaching", in Iustus Lipsius. Europae Lumen et Columen. Proceedings of the International Colloqium, Leuven 17-19 September 1997, ed. G. Tournoy, J. de Landtsheer, and J. Papy, Leuven 1999, pp. 107-123.

4 See J. R. Henderson, "Humanist letter writing: Private conversation or public forum?", in: Self-Presentation and Social Identification. The Rhetoric and Pragmatics of Letter Writing in Early Modern Times, ed. T. van Houdt, J. Papy, G. Tournoy, and C. Matheeussen, Leuven 2002, pp. 17-38. 
of the letter as a separate genre of rhetorical prose. ${ }^{5}$ In vain will we search for any comments concerning the creation of such statements in ancient textbooks of rhetoric. Individual metatheoretical observations can be found in Cicero's or Seneca's letters rather than in Cicero's dialogues and Quintilian's treatise. The letter occupies a separate place in the treatise De elocutione by Demetrius of Phalerum (a fragment concerning writing letters was reprinted together with the discussed treatise by Lipsius), in which the author shows at the same time all the difficulty in elaborating the principles of ars epistolandi from the rhetorical point of view. For the letter, as a quasi-dialogue, is situated on the border between writing and speech, between what is written and what is spoken. This kind of communication situation obviously assumes the empirical absence of the addressee. This question is reversed in ancient rhetoric, which focused on the direct impact on the listener. ${ }^{6}$ The act of pronuntiatio determined the effectiveness of the speaker and was proof of his perfect mastery of rules, which were determined by both the general theory of art (ars) and the ability to use them in practice (facultas).

The issue of presence appears in the definition of letter formulated by Lipsius as soon as he enumerated the names that were used to describe this prose genre (epistula, littera, tabula, tabella, codicillus):

Definio autem epistolam: scriptum animi nuntium ad absentes aut quasi absentes. Animi nuntium dixi, quia finis epistolae duplex: aut affectui testando aut rei significandae.

5 Among the humanists interested in the theory of writing letters, we should certainly mention Erasmus of Rotterdam as the author of Opus de conscribendis epistolis (1522) and his friend Juan Luis Vives, the author of De conscribendis epistolis (1534). See J. L. Vives, De conscribendis epistolis, ed. and transl. Ch. Fantazzi, Leiden 1989.

6 See H. Blumenberg, "O aktualności retoryki w wymiarze antropologicznym”, in: H. Blumenberg, Rzeczywistości, w których żyjemy, transl. W. Lipnik, Warsaw 1997, pp. 115-117. 
[I define the letter as a written communication of thoughts and feelings to people who are absent or as if they were absent. I said "communication of thoughts" because the purpose of the letter is twofold: either to show feelings or to inform about events. ${ }^{7}$ ]

The above definition formulated by Lipsius refers to the rich tradition of thinking about a letter as a written conversation (collocutio scripta, to use the term coined by Saint Ambrose in his Letter XXXVII). It also fits perfectly into the Renaissance theory of epistolography, which stems from the conviction that writing and text suspend or completely abolish the time and space distance between the author and the reader of a given literary work. ${ }^{8}$ Thus, letters become not only written records of a conversation started and then interrupted in anticipation of replies from the addressee, but above all a real presence of the participants in the dialogue, which is extended over time. Lipsius' ars epistolandi is therefore built on the following central idea: the text can make a physically absent person present. This, in turn, implies full identification of the author and his or her work, and the written word is "the medium of representation".

Let us return to the letter Lipsius sent to Schoen. According to Lipsius, each letter consists of two parts, content (materies) and verbal form (sermo), which can then be useful in the analysis of this type of discourse. As far as the content of the letter is concerned, one can distinguish between fixed elements (sollennes) and variable elements (variantes). The parts that are repeated in almost every epistola are the

7 In the Polish version of the paper, the author used excerpts from H. Matyja's translation of the discussed treatise of Lipsius, published in the anthology: Źródła wiedzy teoretycznoliterackiej $w$ dawnej Polsce. Średniowiecze - Renesans - Barok, ed. M. Cytowska and T. Michałowska, Warsaw 1999, p. 396. Quotes in Latin come from: I. Lipsius, Epistolica Institutio, excepta e dictantis eius ore . . Adiunctum est Demetrii Phalerei eiusdem argumenti scriptum, Antverpiae 1605 (BJ 393590 III). See also J. Lipsius, Principles of Letter-Writting. A Bilingual Text of Justi Lipsi Epistolica Institutio, ed. and transl. R. V. Young and M. T. Hester, Carbondale 1996.

8 See J. Domański, Tekst jako uobecnienie. Szkic z dziejów myśli o piśmie i książce, Warsaw 1992, pp. 8-11. 
introduction (praeloqium) and the ending (clausula). They are limited to a set of specific formulas used according to the specific situation (the type of addressee, the nature of the letter, etc.). The introduction is closed with the names (nomina) of the sender (Iustus Lipsius) and the addressee (Andrea Schoneus), as well as a short greeting (salus). The ending includes, among other things, a valediction (valedictio) and a definition of place and time (loci et temporis adiectio).

The uniqueness of a letter is determined only by the variable part, which Lipsius characterises in the following way:

At variantem materiem appello, quae diversa in quaque epistola est, ipsa occassio scribendi et causa. Ea multiplex, nec minus late patet quam haec vita. Quid enim rei divinae aut humanae est, quod non sermone communicamus? Ergo et litteris, quae alter sermo.

[The changeable content of a letter is the content that is different depending on the occasion and reason for writing the letter. The content may be of different sorts: possible subjects are no less extensive than life itself. Are there any of the divine and human affairs that cannot be a subject of conversation? So it is similar in the case of letters, which are also a kind of conversation (p. 398).]

The materies varians of a letter is therefore dependent on the context of its creation, which defines the object of this quasi-conversation. Moreover, the dialogue is here a natural reference point for a theoretical discussion of letters, which affects the way of understanding the role of inventio and dispositio (ordo) in this type of communication. Except for letters described as learned, finding a topic is simply specifying the content of a letter. It is always-so to speak-given to us (when we take a pen, we usually know what we want to write about) or even imposed on us in advance (when we reply to a letter). A similar downgrade may be observed in the case of dispositio. It becomes free and permits an uneven distribution of the subject matter throughout the letter. Sometimes, the clumsiness of the epistolary text is even emphasised to such a degree that it bears no signs of being arranged in any way. This "careful carelessness" in terms of dispositio, combined with Cicero's rhetorical theory (see Orator 23, 78: "neglegentia 
diligens"), makes a letter more like a record of a conversation which is not governed by any previously devised plan:

Nec in ordine quidem admodum laboro, qui optimus in epistola, neglectus aut nullus. Ut in colloquiis incuriosum quiddam et incompositum amamus, ita hic. Adeo ut nec in responsionibus ordine et distincte ad capita semper respondeamus, sed ut visum atque ut hoc illudve in mentem aut calamum venit.

[The distribution [of the matter] is best when it is careless or not orderly at all. We like to talk in a careless way and not to stick to a plan; the same is true of a letter. And even when we answer somebody, we speak without a plan and do not stick strictly to any points, but [we speak] as we please, and what comes to mind and under the pen (p. 399).]

However, the content in the discussed letter can be divided into three parts, one for each of the issues raised. In the first fragment, which plays the role of a short introduction, the use of the traditional exordial loci is discussed. The topos, which consists in explaining the reason for writing a letter (explicatio causae scribendi), is in this case combined with an assurance of the cordial friendship between the sender and the addressee. If it is merely declaratory, it is still assumed that it obliges the sender to reply, just like a question put to someone during a direct conversation. It requires the other person to respond appropriately, even if the proper response turns out to be silence. It is also assumed tacitly that the "you" of the dialogical situation is not limited to being spoken to. Instead, he or she is allowed to speak freely, which a right guaranteed by the alternation of roles in conversation (speaking-listening, or in relation to the letter as "written conversation" respectively: writing-reading). The introduction closes with the topos of presence, which creates a sense of real presence (imago praesentiae) of people who are separated in space but in contact with each other thanks to the text.

The second part of the letter contains Lipsius' comments on the situation in the then Europa litterarum. In his opinion, the beginning of the seventeenth century is when an unexpected time of translatio studiorum seems to come to an end. Studies on the literature of the 
Greeks and Romans (studia humaniora), so far developed in France and Italy, now flourished in numerous cities in Germany and Sarmatia. Important cultural centres in Europe lost significance due to unfavourable conditions for humanistic studies, which brought to the fore cities hitherto considered peripheral and secondary. This process corresponded with the dialectic of the centre-periphery opposition, according to which decentralisation is inevitably accompanied by the revaluation of the peripheral. Therefore, the appreciation of Schoen is mixed with words of amazement at a situation that resists all rational attempts at explication. It could only be explained through the revelation of the order of Divine Providence, which remains inaccessible to human knowledge. The incomprehensibility of this decentralisation is highlighted by the reference to the opinion of ancient Romans. According to them, the borders of the Roman Empire (limes Imperii Romani) delineated a peaceful space (pax Romana) that provided convenient conditions for the creation of literature and literary studies, while the inhabitants of the lands west of the Rhine and north of the Danube were supposed to conduct ceaseless wars, which could not favour such intellectual activities. Lipsius was very familiar with this belief. After all, he was one of the most eminent experts on the history and culture of ancient Rome. However, even the hypothetical transposition of this view of ancient authors (mainly Tacitus) into the realities of Europe at the beginning of the seventeenth century, in which political and religious antagonisms between individual countries (and even regions) that once formed the provinces of the Roman Empire were intensifying, may raise justified doubts. These antagonisms were particularly evident in the historical land of the Netherlands, where Lipsius lived and worked. Following the outbreak of the anti-Spanish uprising in 1566, these areas became the theatre of endless warfare, which transformed wealthy cities into camps of Mars and Bellona. This led to the permanent division of the Netherlands into the Dutch Republic (whose independence was recognised by Spain only in 1648) and the Southern Netherlands. The sound of armour and gunshots scare off the Muses, who are forced to look 
for new places to live. In these unfavourable circumstances, Lipsius ${ }^{9}$ showed astonishing adaptability, changing his confession without much problem depending on the university chairs he occupied (JenaLutheranism, Leiden-Calvinism, Leuven-Catholicism). Many of his contemporaries, and especially his critics and enemies, saw this behaviour rather as a manifestation of religious indifference than as a conscious adoption of a supra-confessional attitude ${ }^{10}$ which he attempted to characterise in his De constantia. ${ }^{11}$ An outstanding example of this way of thinking about Lipsius was to be found in the polemical speech by one of the lecturers of logic and metaphysics at the University of Jena, Thomas Sagittarius, entitled Lipsius Proteus ex antro Neptuni protractus et claro solis expositus (published in 1614).

It is worth remembering that Europe (described illustratively by means of personification, probably a mother hugging her child), about which Lipsius wrote, had rather little in common with a continent torn apart by numerous political and religious conflicts at the beginning of the seventeenth century. He refers very clearly to the idea of the République des lettres, which is a community of scholars, especially those who deal with bonae litterae. Expanding the borders of Europe understood in this way and the appearance of new cultural centres on its map (for example, Cracow with its university, where Schoen lectured, but also Vilnius and the University of Vilnius, which was the

9 See A. Grafton, Bring out Your Dead: The Past as Revelation, Cambridge 2001, pp. 227-243; M. Morford, Stoics and Neostoics. Rubens and the Circle of Lipsius, Princeton 1991; M. Morford, "Towards an intellectual biography of Justus Lipsius-Pieter Paul Rubens", in: The World of Justus Lipsius. A Contribution towards His Intellectual Biography. Proceedings of a Colloqium Held under the Auspices of the Belgian Historical Institute in Rome (Rome, 22-24 May 1997), ed. M. Laureys et al., Brussels-Rome 1998, pp. 387-403.

10 See E. H. T. Levi, "The relationship of stoicism and scepticism: Justus Lipsius", in: Humanism and Early Modern Philosophy, ed. J. Krye and M. W. F. Stone, London 2000, pp. 103-104.

11 It was translated into Polish by Janusz Piotrowicz and published in Cracow (1649) under the title O stałości ksiąg dwoje, barzo rozkoszne i użyteczne. 
easternmost centre of latinitas ${ }^{12}$ ) was made possible by the arousal of interest and studies in antique literature and culture, which entailed the acquisition of knowledge of the universal semiotic code. This knowledge enabled one to recognise and read specific topoi, literary allusions, or the ways of interpreting the most important myths. This specific language facilitated contact with scholars who were part of the République des lettres, created a platform for the exchange of ideas in a friendly dialogue, and made it possible to reach an agreement.

Finally, the third part of the letter provides a short account of the meeting between Lipsius and Jan Tęczyński. Schoen sent his student to Leuven in 1601, where he was to attend Lipsius' lectures and give him Schoen's letter, as well as a panegyric he wrote and entitled Fidus Comes $^{13}$ (its fragment containing praise for its addressee was published together with the letter discussed here). The meeting with Tęczyński consolidated Lipsius' positive opinion of the level of teaching at the University of Cracow. His concluding remarks on the illness and the premonition of impending death allow us to define the character of the letter addressed to Schoen as friendly:

Denique familiarem dico, quae res tangit nostras aut circa nos, quaeque in assidua vita.

[As for the content of the letter of a friendly character, it is a letter that concerns us or matters that concern us and all the affairs of everyday life (p. 399).]

But we must remember that informing the addressee about the details of one's private life and sharing personal experiences with him or her was approved by the tacitly accepted convention of scribere familiariter. It originated from letters of Cicero (Ad familiares) and consisted in writing to someone strange as to a well-known person,

12 See J. Niedźwiedź, "Latinitas w kulturze literackiej Wilna XV-XVIII wieku", Terminus 2 (2004), pp. 41-51.

13 See Belgia w relacjach Polaków. Antologia (XVI-XX w.), ed. M. B. Styk, Lublin 1999, pp. 33-35. 
with whom we have a deep friendship for a long time. This type of epistolary discourse served to break the mutual alienation of those writing and made them active participants of successes and failures.

The notes on the content and structure of the letter are complemented by indications related to the shaping of its verbal structure:

Sermonem appello elocutionem et stili modum epistolae aptum. Is ut talis fiat, dupliciter eum considerabo: universe et distincte. Universe, in toto habitu et conformatione epistolae, distincte, in paribus, id est phrasi et verbis. De habitu igitur sermonis epistolici, praecipio ut quinque ista serves: brevitatem, perspicuitatem, simplicitatem, venustatem, decentiam.

[What I mean by language is elocutio and a style appropriate for a letter. For it to be just that, I will be considering it in two points, that is to say, in general and in detail. In general, i.e. taking into account the entire character and scope of the letter. In detail, that is by analysing individual parts, or sentences and words. As for the characteristics of epistolary expression, you should strive for conciseness, clarity, simplicity, elegance, and decency (p. 400).]

By focusing on the letter as sermo, Lipsius introduces questions that were traditionally associated with elocutio into epistolographic reflection. What is more, he modifies the most important concepts only slightly so that they can be used when discussing the lexical-syntactic structure of the letter.

Instead of dividing language expressions into single words (verba singula) and combined words (verba coniuncta), Lipsius proposes two levels of stylistic analysis: words (verba) and phrases (phrases). ${ }^{14}$ He also makes certain adjustments to the advantages of elocution (virtutes dicendi), emphasising conciseness (brevitas) and making it the most important quality of this type of expression. A number of formal guidelines, which were supposed to help achieve this virtue

14 "Dixi universe de sermone: magis distincte ad partes eius transeo, phrasim et verba. Illam appello, voces duas aut plures in sententia iunctas. Haec voces ipsas singulas. In illis elegantia et nitor requiritur, in his latinitas et proprietas. Ea omnia hodie, vel ex auditu haurienda sunt, vel ex lectione”. 
(virtus), are arranged in a style characteristic understood as a specific manner of writing (expressing thoughts in language), especially preferred in letters:

Qui fiet igitur sermo brevis? Observatione triplici: rerum, compositionis, verborum. Rerum, ut supervacuum nihil admisceas, nil repetas, imprimis non capita ad quae respondes. Compositionis, ut structuram et periodum longiorem omnem fugias, membris utare et asyndetis saepe. Verborum, ut laetior omnis phrasis, allegoria, imago abdicetur, parca et pura oratio sit, necessaria supellectile verborum contenta.

[So what makes a statement concise? There are three things to care about: the content, the arrangement, the words. As for the content, you are not to add anything unnecessary nor to repeat anything, above all, not the issues you are referring to. As for the layout, avoid too elaborate a structure and too long a period, use elements that are often asyndetic. As for the words, there is no room for overly refined expressions, allegories, vivid descriptions; the speech is to be modest and pure, limited to a necessary set of words (p. 401).]

The category of style plays a superior role in Lipsius' theoretical exposition of the principles of epistolography because it combines two basic levels on which a letter is organised, namely the semantic content of a letter with its linguistic "packaging". Moderation in the use of rhetorical figures translates into the construction of rhetorical periods that should not be too extensive, and their individual elements should connect without conjunctions (asyndetically). The question of rhetorical brevitas (Erasmus also discussed it in his treatise on copia verborum ac rerum) naturally entailed the following problem: how to reflect the diversity and richness of meaningful expressions with limited linguistic resources? Other values appreciated in rhetoric can also help make a letter concise. Clarity (perspicuitas) ${ }^{15}$ ensures the use of words appropriate to the specific case discussed. Simplicity

15 "Clare ergo scribito, si potes et breviter, sed ita, ut hoc laudis esse scias, illud necessitatis. Clarus autem sermo erit praecepto triplici: si verba in eo propria, si usitata, si collocata". 
(simplicitas $)^{16}$ is manifested in the use of everyday vocabulary, as well as a simple and unsophisticated manner of argumentation. Elegance (venustas),${ }^{17}$ which remains largely dependent on innate talent (ingenium), concerns not only the linguistic aspect of the letter, but rather the way of creating expressions so as to make the reader interested in the issues raised. Hence the recommendation to diversify the epistolary discourse by introducing proverbs, allusions to widely known mythical or historical stories, and maxims in both languages. The listing of the advantages of elocution closes with decency (decentia).$^{18}$ Lipsius explains it invoking the postulate of the appropriateness of expression, which depends on one's individual sense of tact.

The above adumbrative reconstruction of Lipsius's ars epistolandi provides an opportunity to ask a question about the relations between rhetoric and the art of writing letters. The answer seems obvious, especially when we consider rhetoric to be the most general theory of creating discourse. However, specific applications of rhetorical rules in epistolography are more than a simple translation of these guidelines from speech to writing. They need to be modified in order to preserve the genre-specific qualities of the letter. Such an attempt was made by Lipsius. He proposed a set of functional categories taken

16 "Tertiam virtutem posui simplicitatem: intellectu duplici, quia et in stilo eam exigo et in mente. De stilo, certum et veterum exemplo testatum est, simplicem eum esse debere, sine cura, sine cultu, simillimum cottidiano sermoni ... At de mente, ita intellego, ut simplex quiddam et ingenuum in tota scriptione eluceat et aperiat candorem quemdam liberae mentis. Nulla enim ex re magis natura cuiusque et certa indoles elucet (Demetrio vere scriptum) quam ex epistola".

17 "Venustatem appello, cum sermo totus alacer, vivus, erectus est et allicientem quamdam gratiam veneremque praefert. Quod natura fere dat, nonnihil tamen et duplex haec monitio. Primum, ut adagia allusionesque ad dicta aut facta vetera, versiculos aut argutas sententias utriusque linguae interdum immisceas. Secundum, ut iocis salibusque opportune condias, quos animam et vitam epistolae esse non fugiam dicere".

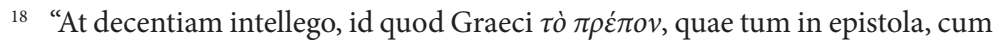
omnia apte et convenienter scripta. Quod fiet aspectu duplici: personae et rei. Personae dupliciter, si tuam respicis et eius ad quem scribis. Rei autem simpliciter, ut omnia pro argumento et sententiarum phrasiumque vestis apta sit corpori rerum". 
from the terminology of rhetoric (clearly privileging stylistic matters). On the one hand, they formed the basis for an intelligible exposition of the art of writing letters, and on the other hand, they were a set of concepts extremely useful in the proper, that is, adequate from the historical point of view, reading of letters-considered, in the days of Demetrius of Phalerum, as half of a conversation (pars dialogi).

Iustus Lipsius,

Andreae Schoneo, viro clarissimo, salutem dicit

Languor me habebat, nec ab eo promptus eram ad scribendum, tamen me fecit tuus amor, mi Schonee, quem in litteris ita palam, quam si in ore atque oculis, ostendis. Itane procul et in illis quoque regionibus ego, id est litterae, amantur? Num quia libasse eas censeor, vos in me inclinatis? Gaudentem et libentius, quo eundum est, euntem, quod spem relinquam doctrinae in Europa haesurae, quae vos etiam in ultimo eius limite adspexit, imo arctiori amplexu sibi iunxit. Deus bone, quis bono et veteri aevo de vobis hoc iactasset? Cum horror illic et squalor, nec nisi Martis sedes et incolis cordi

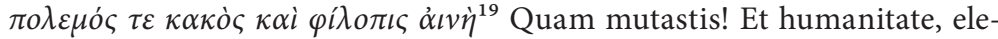
gantia, omni cultu animi provocare audetis lectissimam quamque gentem! Mirus Providentiae ordo! Et caelestis ille agricola has illasque partes excolit et velut novales quosdam agros alternis serit. ${ }^{20}$ Quid Graeci, quid placent sibi Itali? Graecia et Italia nuper in Gallia et nunc in Germania aut Sarmatia reperiuntur. Macti estote, applaudimus et tibi privatim, mi Schonee, qui utraque oratione, soluta et ligata, potes pollesque ${ }^{21}$. Vidi enim et ipse ille qui attulit, Comes Tenczinius, lumen et decorum infudit, nobili stirpe atque animo iuvenis et qui crescit in laudem vestri regni. Hac quoque parte vos

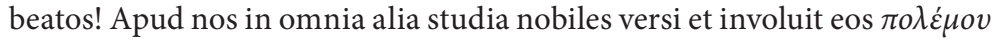

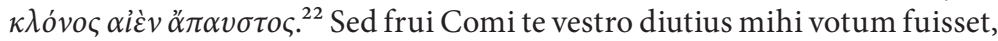
lingua diserto et prompto, mente et iudicio bono, sed via eum trahebat, me languor sistit, non aliquis novus, sed ille vetus et qui in tam pertinace lucta

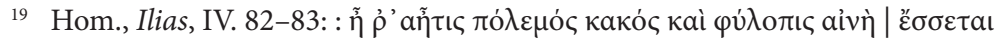

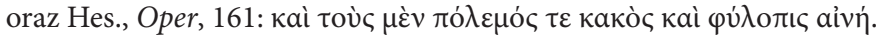

20 Verg. Georg., I 71: “alternis idem tonsas cessare novalis".

21 Liv., Ab urbe cond., I, 24: "tantoque magis ferito quanto magis potes pollesque".

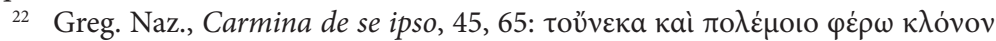

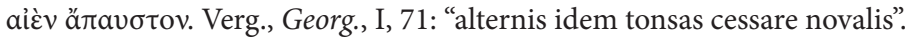


me deiicit, vel supplantat. Bona fide ego ut me sentio ad metam - quid mali aut novi? Omnes una manet nox et calcanda semel via leti. ${ }^{23} \mathrm{Tu}$ longum longinque vale, mi Schonee, et optimas ibi artes propaga.

Lovanii, postridie Idus Martii, MDCII.

Iustus Lipsius

sends his greetings to the famous Andrzej Schoen.

I got ill, and it has not been easy for me to write, but I felt motivated by your love, my Schoen, which you showed me in your letter as openly as if I had seen you and talked to you. So I am, or literature is, loved so deeply even in these countries? Maybe you are inclined to me because I am thought to be well versed in literature? I therefore rejoice and I am glad to go where we all need to go because there is hope that erudition in Europe will survive, which has also found you at its frontier and even drew you to itself with a stronger embrace. Dear God, who would dare to say something like that about you in the good old times? Since there are horror and darkness, nothing but the camps of Mars, and "evil war and terrible struggle" in the hearts of the inhabitants. How have you changed! And you dare compete with all the greatest peoples in the liberal arts, elegance, and all the disciplines of the mind! An astonishing act of Providence! So this divine Farmer cultivates different lands alternately, and between whiles, he sows each of them like a fallow field. Why the Greeks, why are the people of Italy satisfied with themselves? Not long ago did Greece and Italy find themselves in Gaul, and now in Germania or Sarmatia. May you grow; we applaud you. Especially you, my Schoen, recognised and famous for your mastery in both kinds of speech, plain and versified..$^{24}$ For I noticed that even the one who delivered the letter, Count Tęczyński, ${ }^{25}$ turned out to be full of splendour and

23 Hor., Car., I, 28, 15-16: "Sed omnis una manet nox | et calcanda semel via leti".

${ }^{24}$ The term oratio soluta (possibly libera, prolixa), i.e. free and plain speech (by default: free from the rhythmic organisation of the phrase imposed by an adopted metre) means prose, while the term oratio ligata (or vincta, astricta), i.e. speech bounded and limited by the metre, refers to poetry.

25 Jan Magnus Tęczyński (1579-1637), coat-of-arms Topór, Voivode of Cracow in the years 1620-1637, the Great Crown Cup-Bearer, patron of Piotr Kochanowski, who dedicated his "new rhymes on the liberation of Jerusalem" to Tęczyński, addressing him in the following way: "my honour and adornment, Count of Tęczyn". 
magnificence of learning as a young man of great family and mind, who grows to the glory of your Kingdom. How lucky you are in this respect, too! In our country, the noble-born turned to all other passions and became engulfed by "the endless muddle of quarrels". I wanted to enjoy the company of Count Tęczyński, his eloquent language, good mind and judgement for a longer time. However, he was called by his journey, I was stopped by a disease, not a new one, but an old one, which in this constant struggle blows me down and even devastates me. I honestly think that I am approaching the end of my life-what is wrong or new with that? The same night awaits all of us. And the road of death is to be tread only once. Farewell forever, my Schoen from the farthest lands, and teach the best of the arts there.

Leuven, 16 March 1602

Translated from Polish by Kaja Szymańska

\section{Bibliography}

Belgia w relacjach Polaków. Antologia (XVI-XX w.), ed. M. B. Styk, Lublin 1999. Blumenberg H., "O aktualności retoryki w wymiarze antropologicznym", in: H. Blumenberg, Rzeczywistości, w których żyjemy, transl. W. Lipnik, Warsaw 1997, pp. 115-117.

Borowski A., Iter Polono-Belgo-Ollandicum. Cultural and literary relationships between the Commonwealth of Poland and the Netherlands in the $16^{\text {th }}$ and $17^{\text {th }}$ centuries, Cracow 2007.

Domański J., Tekst jako uobecnienie. Szkic z dziejów myśli o piśmie i książce, Warsaw 1992.

Fumaroli M., L'Âge de l'éloquence : rhétorique et "res literaria » de la Renaissance au seuil de l'époque classique, Genève 1980, pp. 152-159.

Grafton A., Bring out Your Dead: The Past as Revelation, Cambridge 2001.

He maintained lively contacts with the professors of the Academy of Cracow. His daughter Izabela became the wife of Krzysztof Opaliński. The founder of the Carmelite monastery in Czerna near Krzeszowice and the Camaldolese monastery in Rytwiany. 
Henderson J. R., "Humanist letter writing: Private conversation or public forum?", in: Self-Presentation and Social Identification. The Rhetoric and Pragmatics of Letter Writing in Early Modern Times, ed. T. van Houdt, J. Papy, G. Tournoy, and C. Matheeussen, Leuven 2002, pp. 17-38.

Levi E. H. T., "The relationship of stoicism and scepticism: Justus Lipsius”, in: $\mathrm{Hu}$ manism and Early Modern Philosophy, ed. J. Krye and M. W. F. Stone, London 2000, pp. 103-104.

Lipsius I., Epistolica Institutio, excepta e dictantis eius ore . . . Adiunctum est Demetrii Phalerei eiusdem argumenti scriptum, Antverpiae 1605.

Lipsius J., Principles of Letter-Writting. A Bilingual Text of Justi Lipsi Epistolica Institutio, ed. and transl. R. V. Young and M. T. Hester, Carbondale 1996.

Morford M., "Life and letters in Lipsius's teaching", in Iustus Lipsius. Europae Lumen et Columen. Proceedings of the International Colloqium, Leuven 17-19 September 1997, ed. G. Tournoy, J. de Landtsheer, and J. Papy, Leuven 1999, pp. 107-123.

Morford M., Stoics and Neostoics. Rubens and the Circle of Lipsius, Princeton 1991.

Morford M., "Towards an intellectual biography of Justus Lipsius-Pieter Paul Rubens", in: The World of Justus Lipsius. A Contribution towards His Intellectual Biography. Proceedings of a Colloqium Held under the Auspices of the Belgian Historical Institute in Rome (Rome, 22-24 May 1997), ed. M. Laureys et al., Brussels-Rome 1998, pp. 387-403.

Niedźwiedź J., "Latinitas w kulturze literackiej Wilna XV-XVIII wieku”, Terminus 2 (2004), pp. 41-51.

Vives J. L., De conscribendis epistolis, ed. and transl. Ch. Fantazzi, Leiden 1989.

Źródła wiedzy teoretycznoliterackiej w dawnej Polsce. Średniowiecze - Renesans Barok, ed. M. Cytowska and T. Michałowska, Warsaw 1999. 
